\title{
After Most Recent Visit
}

National Cancer Institute

\section{Source}

National Cancer Institute. After Most Recent Visit. NCI Thesaurus. Code C148466.

Happening after a patient's most recent visit. 